Article

\title{
Port Noise and Complaints in the North Tyrrhenian Sea and Framework for Remediation
}

\author{
Matteo Bolognese ${ }^{1}$ (D), Francesco Fidecaro ${ }^{1}$ (D), Diego Palazzuoli ${ }^{2}$ and Gaetano Licitra ${ }^{2, *(D)}$ \\ 1 Physics Department "Enrico Fermi", University of Pisa, Largo Bruno Pontecorvo 3, 56127 Pisa, Italy; \\ m.bolognese@studenti.unipi.it (M.B.); francesco.fidecaro@unipi.it (F.F.) \\ 2 Environmental Protection Agency of Tuscany Region, via V. Veneto 27, 56127 Pisa, Italy; \\ diego.palazzuoli@arpat.toscana.it \\ * Correspondence: g.licitra@arpat.toscana.it or gaetano.licitra@arpat.toscana.it
}

Received: 24 November 2019; Accepted: 20 February 2020; Published: 24 February 2020

\begin{abstract}
Compared to the other relevant noise sources such as railways, roads, and airplanes, the regulation regarding port noise is lagging behind. The absence of specific laws is likely one of the main causes of the increasingly high number of complaints reported by the citizens living nearby the ports. At the same time, scientific literature concerning the impact of port noise and its mitigation is not so widespread and only a few studies are available at the moment. However, the volume of maritime traffic has increased in the last years and consequently, Port Authorities are required to assess the impact of port operations on the city soundscape without using specific directives or guidelines. In this context, the INTERREG Maritime programme projects RUMBLE, MON ACUMEN, and REPORT aim to fill this gap, by investigating the state-of-the-art of port noise in the north Tyrrhenian sea and developing helpful instruments. Data were collected via a survey sent to the Port Authorities, local environmental protection agencies and universities involved in the projects. The survey was focused on monitoring systems, previous measurement campaigns, noise maps, and citizens' complaints already taken. The results confirmed both a lack of awareness among residents and authorities and the absence of actions aimed at reducing port noise. In this framework, the difficulties encountered by the Port Authorities in managing the ports sustainably are highlighted. An underestimation of citizens' exposure to noise in port areas could be expected.
\end{abstract}

Keywords: port noise; Interreg project; noise complaints; noise management; noise prevention; noise action plans

\section{Introduction}

Exposure to environmental noise can cause problems for human health, such as cardiovascular and respiratory diseases [1-5], hypertension [6,7], annoyance [8-10], learning difficulties [11-13], and sleep disturbance [14].

The port environment is extremely various and heterogeneous both in terms of usage and in terms of intensity of the activities at different times. Due to the presence of a wide range of noise sources such as trains, heavy vehicles, ships, and industrial machines operating simultaneously, the port area is more complex to study than other noise sources. Additionally, the ports are usually surrounded by other big transportation infrastructures and by urban areas that are widely affected by the produced noise even at large distances due to the low-frequency noise produced from the ships' internal power generator.

The typical noise sources of the ports are ships, which produce different noise levels and have different directivity according to their type. As well as for all the other port noise sources, a simple classification based on source class is not enough, an accurate classification should be based on the specific operation performed by the ship. For example, a boarding ship produces a very different noise 
than a ship at berth. The low-frequency noise emitted by the engine of a docked ship produces a higher impact at night often at long distances, due to the low level of background noise, while the impulsive noise caused by heavy vehicles going in and out of a ship is very impactful even during the day when the background noise is higher.

Noise emissions of the port are not only produced inside the port area, but the induced terrestrial traffic causes sound emission all over the surrounding urban environment. However, it is almost impossible for citizens to discern between the traffic related to port activities and traffic due to other activities in the area. Therefore, the assessment of the noise impact of ports cannot be based only on citizens' complaints. Therefore, a study aimed at the evaluation of the effects of port-induced traffic on terrestrial transportation networks is critical.

In general, each port requires individual evaluation since its traffic composition is different; moreover, the port itself is characterized by different types of noise sources depending on the main activities present, so this aspect must be considered for a first approach to the acoustic characterization of port areas.

Unfortunately, both in Italy and France, specific decrees related to port noise have yet to be released. The European Noise Directive 2002/49/EC (END), aimed at the reduction of noise exposure, requires the Member States to provide noise maps related to road, rail, airport and industrial sources and action plans for its progressive reduction, but it does not devote enough attention to ports and surrounding areas.

The recent flourishing of European projects such as HADA [15], EcoPort [16], NoMEPorts [17], SIMPYC [18], MESP [19], and Anchor [20], give evidence of a keen interest in the theme, despite the small number of scientific papers on port noise and the absence of a complete understanding and description of the phenomena involved.

In the close future, the great funds granted to maritime traffic and government initiatives like the 21st Century Maritime Silk Road [21] will likely result in an increase of traffic volume and, therefore, noise levels in port areas are expected to rise, unless efficient measures on both noise mitigation and noise management will be adopted.

This work presents the results of a survey on port noise developed under the INTERREG Maritime projects RUMBLE [22], MON ACUMEN [23], and REPORT [24]. In short, a questionnaire was sent to port authorities, universities, regional environmental protection agencies and other public institutions involved in the port noise, in order to provide a description of the state-of-the-art concerning port noise in the area of the North Tyrrhenian Sea. The aim of the work is to estimate the exposure of citizens and to assess the current awareness of port authorities. For this purpose, all available data on port management, main port activities present, main sources, past measurement campaigns, active monitoring systems, and citizens' complaints were collected.

\section{Ports of the North Tyrrhenian Sea}

Some of the biggest ports of southern Europe and the Mediterranean Sea are located in the region of the North Tyrrhenian sea. A list of the biggest ports in the area and passengers and freight traffic volumes is reported in Table 1. The two major ports of the area are described below.

Table 1. Passengers and freight traffic volumes of the biggest ports in the North Tyrrhenian Sea.

\begin{tabular}{ccccc}
\hline Port & Tons $^{\mathbf{1}}$ & TEU $^{\mathbf{2}}$ & Passengers $^{\mathbf{3}}$ & Population $^{2}$ \\
\hline Genoa & $50,662,000$ & $2,554,202$ & $2,259,000$ & 578,000 \\
Livorno & $30,265,000$ & $1,181,737$ & $2,401,000$ & 157,767 \\
La Spezia & $15,625,000$ & $1,652,582$ & 0 & 93,347 \\
Cagliari & $11,464,000$ & 430,706 & 348,000 & 154,267 \\
Bastia & $1,299,000$ & 0 & $2,925,000$ & 44,165 \\
Nice & 0 & - & $2,165,000$ & 344,460 \\
Portoferraio & 579,000 & - & 679,000 & 12,004
\end{tabular}

${ }^{1}$ Eurostat $[25,26] .{ }^{2}$ Twenty-foot equivalent unit (TEU), used to describe the capacity of container ships and container terminals [27]. ${ }^{3}$ Eurostat, excluding cruise passengers [28,29]. 


\subsection{Port of Genoa}

The port of Genoa, together with the Ports of Prà, Savona, and Vado constitute the major Italian port system in terms of total traffic (70,000,000 tons of goods and 4.3 million passengers). Moreover, the port of Genoa is the biggest Italian port and one of the biggest ports in the Mediterranean Sea: it comprises an area of 700 hectares of land and 500 hectares on water, stretching for over $22 \mathrm{~km}$ along the coastline and possesses $47 \mathrm{~km}$ of maritime ways and $30 \mathrm{~km}$ of operative quays. The port is involved in several activities and is organized in different areas according to their usage (Figure 1):

1. commercial;

2. passengers;

3. shipyards;

4. oil and gas;

5. boating.

The port is surrounded by the city of Genoa that is densely populated (578,000 inhabitants distributed mainly around the port) and large transport infrastructure like highways, railways, and an airport form a close-knit network around the port.

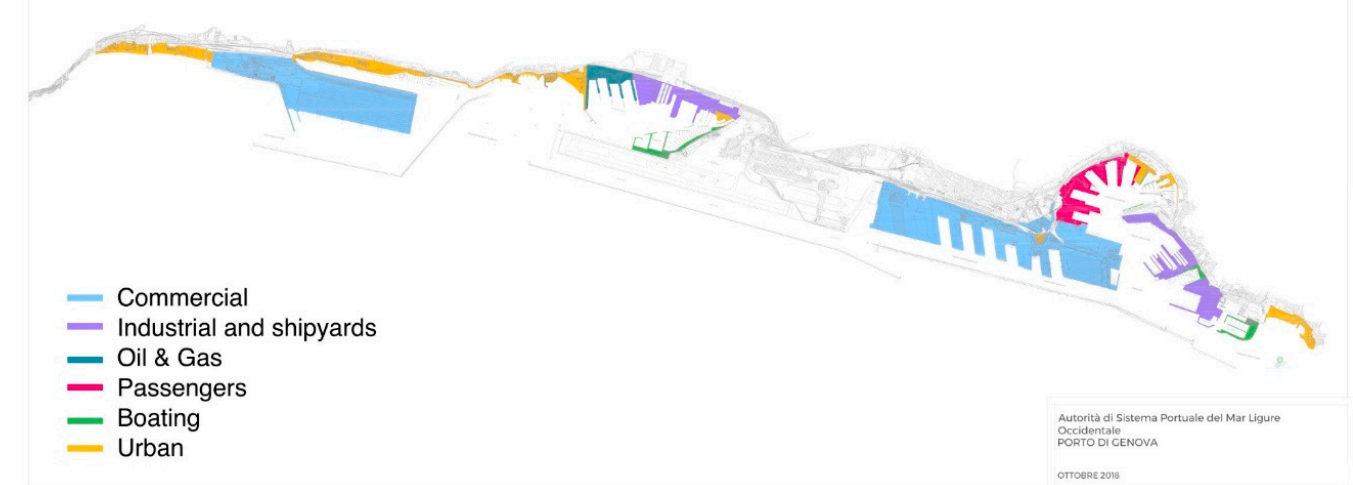

Figure 1. Area of usage of the port of Genoa.

\subsection{Port of Livorno}

The port of Livorno is the biggest of Tuscany and one of Italy's main port. Inside the port are passenger terminals, commercial terminals, container terminals and a variety of industrial plants from the paper industry to the storage of cereals. Figure 2 presents an image of the port of Livorno taken by an acoustic camera, capable of identifying the noise sources within the frame.

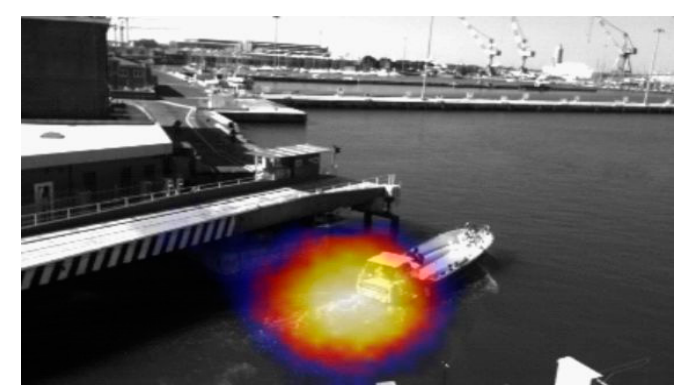

Figure 2. Image produced by an acoustic camera in the port of Livorno. 


\section{Characterization of Port Areas}

As mentioned above, in the port areas there are many different noise sources whose importance depends on the duration of the activities. In this paragraph, the main relevant sources in different port areas will be described.

\subsection{Container Terminal}

The container terminal is characterized by the presence of many noise sources operating continuously. The more common noise sources are cranes, gantry cranes, gate cranes, reach-stackers, and terminal tractors. In particular, attention should be devoted to the acoustic security alerts that produce a very loud noise every time a crane or an articulated vehicle is operating.

An online survey regarding Genoa port noise suggested that noise produced by security alerts was perceived as one of the most disturbing by the citizens. The impact of containers against the metallic surface of the ships and on the ground; from ships' motor, and generators; traffic noise and non-respectful attitudes, like honking and sudden accelerations and braking were also mentioned as highly disturbing.

\subsection{Passengers Terminal}

The passenger terminals are mainly occupied by ferries and cruise ships. In these type of ships, the aeration vents, the funnels, and the generators are the main noise sources. Moreover, during boarding and disembarking procedures, heavy and light vehicles may cause impulsive noise due to the impact of the platform on the quay.

\subsection{Shipbuilding and Industrial Plants}

Shipbuilding areas are characterized by the presence of high noise sources like drills, presses, and circular saws that can be very disturbing for citizens. Industrial plants are also commonly found within the boundaries of the port and noise emission is not always negligible in certain circumstances, depending on production activities.

\subsection{Induced Terrestrial Traffic}

A noise source common to all ports is the induced terrestrial traffic constituted by transportation vehicles like trains and heavy and light-weight vehicles entering or exiting the port area. Because of the intrinsic characteristics of these sources, their impact can be perceived even far away from the port area and is difficult to identify without a specific study.

\section{Interreg Projects}

The INTERREG Maritime programme is aimed at filling the gap in knowledge regarding port noise [30] and is currently developing different studies to describe the state-of-the-art and pinpoint the best practices in terms of long-term sustainability in the area of north Tyrrhenian. The Interreg Maritime approved projects aiming to assess different aspects of the port noise are:

1. REPORT: aimed to develop simulation models, noise evaluation, and noise control strategies producing guidelines;

2. DECIBEL: aims at the realization of infrastructures for noise reduction in small ports [31];

3. L.I.S.T. PORT: has the purpose of developing logistics and management models for lightweight and heavyweight vehicle traffic from and to the ports [32];

4. MON ACUMEN: has the objective of developing a common monitoring system on the North Tyrrhenian ports;

5. RUMBLE: aims to realize noise reduction infrastructure in big ports. 


\subsection{RUMBLE}

Project RUMBLE approaches the problem of port noise aiming at the mitigation of noise. The aim of the project is to realize a series of noise mitigation infrastructures in big ports of the study area, in order to evaluate the efficiency and the sustainability of such actions. The final goal is to establish the right kind of infrastructure in the different port scenarios, in order to allow the port authorities to choose the most appropriate action based on the distinctive port characteristics.

\subsection{MON ACUMEN}

MON ACUMEN is an acronym for "MONitorage Actif Conjoint Urbain-MaritimE de la Nuisance". The project aims at tackling noise monitoring and noise management in the port area, in order to allow port authorities to manage port activities in a sustainable way. The project started with an in-depth analysis of the state-of-the-art concerning port noise, noise monitoring, noise measurement, and acoustic characterization of port-specific noise sources. Noise maps of the involved ports are needed to correctly design the monitoring infrastructure (Figure 3). More specifically, a relation between the different port activities and noise levels at the receivers would allow the project to correctly pinpoint the monitoring position. The goal is to build an integrated monitoring net, following common rules for all the ports in the area, that allows real-time simultaneous noise-monitoring of all the ports and, in the case where noise exceeds the limits, identify the responsibe source.

\subsection{REPORT}

The objective of the REPORT project is to define new algorithms and methodologies in different sectors, in order to define the best common and cross-border replicable strategies for noise abatement. The aim is to find the means to deal with the aspect of noise management in the port area in a complete and sustainable way. The focus areas of the project are:

1. Modeling noise sources in the port area and development of a dedicated tool in the acoustic simulation software;

2. Evaluating the benefit in terms of the acoustic impact of the introduction within the port environment of alternative propulsion technologies like Liquified Natural Gas [33], plug-in hybrid electric vehicles, and full electric vehicles;

3. Developing a neural-engine driven prevision software for traffic and noise capable of real-time estimation of the noise level in specific critical points if the city;

4. Evaluating comparatively the social costs incurred by the local population and the tourists in the surrounding area of ports because of the noise pollution;

5. Evaluating the usefulness and applicability of the CNOSSOS [34] model in port areas.

After the development of the above studies and the conclusion of the other Interreg projects, the REPORT project will act as a collector for all the results with the aim of producing integrated and comprehensive guidelines about best practice on port noise management.

For all three projects, common needs, such as collecting all data relating to the port area from the public bodies involved have been identified. With regards to the RUMBLE project, the objective is to determine where the planned infrastructure would be built, while the identification of critical areas in terms of noise impact around the port is the objective of the MON ACUMEN project. REPORT and MON ACUMEN projects are involved in the data collection campaign, because of the need for a cross-border report regarding port regulations' state-of-the-arts. 


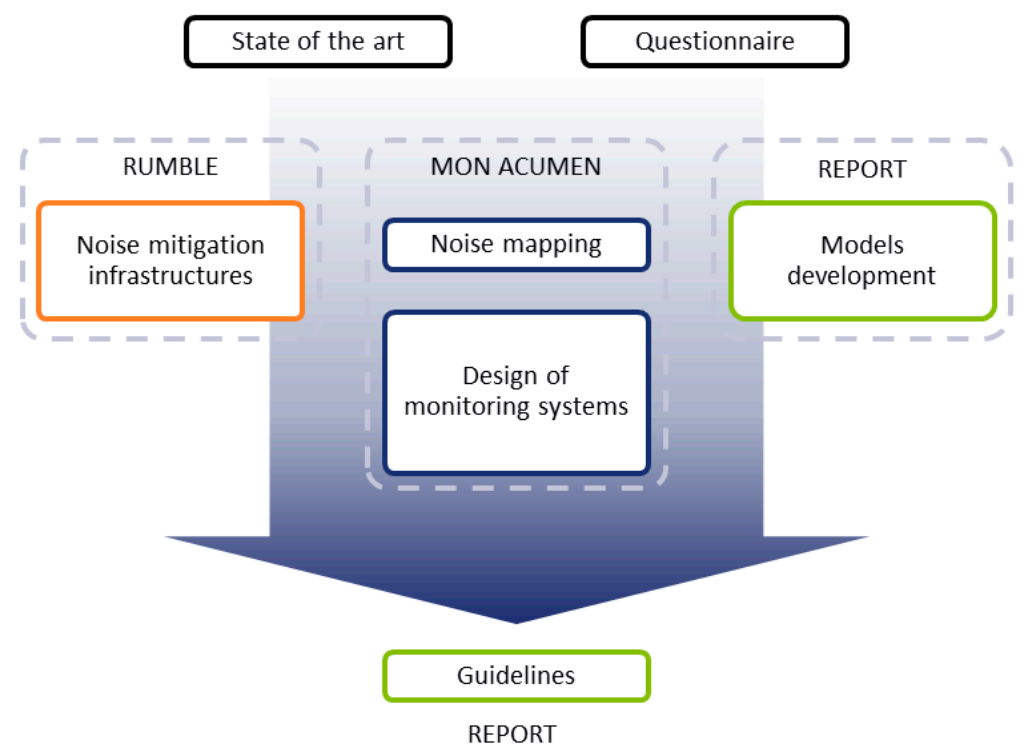

Figure 3. Structure of the Interreg projects activities.

\section{Materials and Methods}

The first step in filling the knowledge gap in the matter of port noise is to collect all the available information, including both objective (such as monitoring campaigns, scientific studies etc.) and subjective data (i.e., complaints). For this reason, additional questions regarding the main aspects of the three projects were included and a common survey was realized and sent to all the stakeholders involved. As the organizations were called to answer the questions, even ones not directly related to their respective projects, a larger database was built.

In the first instance, a form was sent to the partners using their institutional e-mail. After receiving weak feedback, a dedicated website was realized to make it easier to answer the questionnaire.

\section{Survey Structure}

The survey contained the following details:

1. Personal data;

2. Description of the port area;

3. Noise monitoring systems;

4. Measurement campaigns;

5. Noise mapping;

6. Complaints and committees;

7. Regulations.

The first section collected the information necessary to identify the public body answering the questionnaire with all related port data like type of public body; website; address etc. A single body could answer for more than one port, for example, the Environmental Protection Agency of Liguria Region (ARPAL) could have answered for Genoa and La Spezia or the Livorno Port Authority answered for Portoferraio and Livorno, both under its control. That type of information was needed because an on-line version of the questionnaire was made. This section also asked for the contact details of the management and the contact details of the body.

The "Description of the port area" section requested the respondee to provide a description and classification of the port area accompanied by georeferenced satellite images and port maps with areas of use. A detailed description of the port area is fundamental for the projects since MON ACUMEN designs the monitoring systems and RUMBLE identifies the areas of intervention. 
As mentioned above, knowledge of active monitoring systems is essential for all three projects to understand the current state of the ports under consideration. The "Noise monitoring systems" section asked for a precise description of the monitoring systems, paying attention to data management, data availability and readability. This work step is essential for MON ACUMEN because its objective is to define a common monitoring standard for the Italian-French cross-border area of the Tyrrhenian Sea.

Data on previous monitoring campaigns were required in the "Measurement campaigns" section as they are of fundamental importance in the definition of the acoustic climate.

The "Noise mapping" section required the description of the mapping carried out according to Directive 49/2002/EC of the Action Plans. Knowing the contributions generated by other infrastructures such as railways, roads, and airports are essential to properly assess the noise impact of ports.

The "Complaints and committees" section required the estimation of the number of citizens exposed by port noise, the classification of disturbing sources, the georeferenced maps showing the position of disturbing sources and exposed receivers, and the information on complaints presented by citizens. Information on noise prevention committees with a specific focus on port noise was also required.

Lastly, the "Regulations" section provides a series of in-depth questions about the existing regulatory framework and the tools provided by the management bodies.

\section{Results}

Table 2 shows the public bodies involved and their project affiliation. The response to the survey was not complete and none of the questionnaire answers can be considered as fully comprehensive, despite all the partners having been asked many times to contribute. The request to answer was also reiterated during the project meetings but, as can be seen from Table 2, some partners have not answered. University of Pisa (UNIPI) did not reply to the questionnaire since they handled the data collection process.

Table 2. The main bodies involved in the campaign and the projects in which they participate.

\begin{tabular}{|c|c|c|c|c|c|}
\hline Public Body & Answer & Port & $\begin{array}{c}\text { MON } \\
\text { ACUMEN }\end{array}$ & RUMBLE & REPORT \\
\hline Regione Liguria & Yes & Genoa & - & Yes & - \\
\hline OTC $^{1}$ & No & - & - & Yes & - \\
\hline University of Genoa & Yes & Genoa & Yes & Yes & Yes \\
\hline University of Pisa & No & - & - & Yes & Yes \\
\hline AdSPMLOc $^{2}$ & Yes & Genoa & Yes & Yes & - \\
\hline AdSPMLO $^{3}$ & Yes & La Spezia & Yes & - & - \\
\hline APS MTS ${ }^{4}$ & Yes & Livorno Portoferraio & Yes & Yes & - \\
\hline ASP MS $^{5}$ & Yes & Cagliari & Yes & Yes & - \\
\hline Nice Cote D'Azur & Yes & Nice & - & Yes & - \\
\hline $\mathrm{CCI}^{6}$ & Yes & Nice & - & - & - \\
\hline $\mathrm{CCI} 2 \mathrm{~B}^{7}$ & Yes & Bastia & Yes & - & - \\
\hline ARPAT $^{8}$ & Yes & Livorno & Yes & - & Yes \\
\hline CSTB $^{9}$ & No & - & - & - & Yes \\
\hline $\mathrm{UCPP}^{10}$ & No & - & - & - & Yes \\
\hline University of Cagliari & No & - & - & - & Yes \\
\hline ARPAL $^{11}$ & Yes & La Spezia & - & - & - \\
\hline
\end{tabular}

${ }^{1}$ Office des Transports de la Corse. ${ }^{2}$ Autorità di Sistema Portuale del Mar Ligure Occidentale (Genoa Port Authority). ${ }^{3}$ Autorità di Sistema Portuale del Mar Ligure Orientale (La Spezia Port Authority). ${ }^{4}$ Autorità di Sistema Portuale del Mar Tirreno Settentrionale (Livorno Port Authority). ${ }^{5}$ Autorità di Sistema Portuale del Mar di Sardegna (Cagliari Port Authority). ${ }^{6}$ Chambre de Commerce et d'Industrie de Nice. ${ }^{7}$ Chambre de Commerce et d'Industrie de Bastia et de la Haute-Corse. ${ }^{8}$ Agenzia Regionale per la Protezione Ambientale Toscana (Environmental Protection Agency of Tuscany Region). ${ }^{9}$ Centre Scientifique et Technique du Bâtiment. ${ }^{10}$ Université de Corse Pasquale Paoli. ${ }^{11}$ Agenzia Regionale per la Protezione Ambientale Liguria (Environmental Protection Agency of Liguria Region). 
In the following, a detailed analysis of the main results will be provided.

\subsection{Monitoring Systems}

As shown in Table 3, the only port equipped with noise monitoring systems is the port of Nice, which yields data compliant with the INSPIRE Directive [35]. Data collected by the monitoring system in Genoa, which is the property of a concession holder, are not public and are not available to the port authority. The monitoring system installed in the port area of Nice consists of seven sound level meters (five Class 2 sound level meters and two Class 1 sound level meters) that allow continuous monitoring of noise levels. Nice Cote D'Azur holds two sound level meters, the first one is a Class 1 produced by Acoem while the second is a Class 2 sound level meter made by Hager, while CCI holds five sound level meters produced by Hager. The positioning of the sound level meters around the port is shown in Figure 4. By the end of 2019, an additional 3 Class 1 sound level meters will be installed. The system monitors yachts and pleasure boats at berth, vehicle traffic, commercial activities, events, protest demonstrations, and construction sites in the vicinity of the port to identify the main noise source in case of complaints.

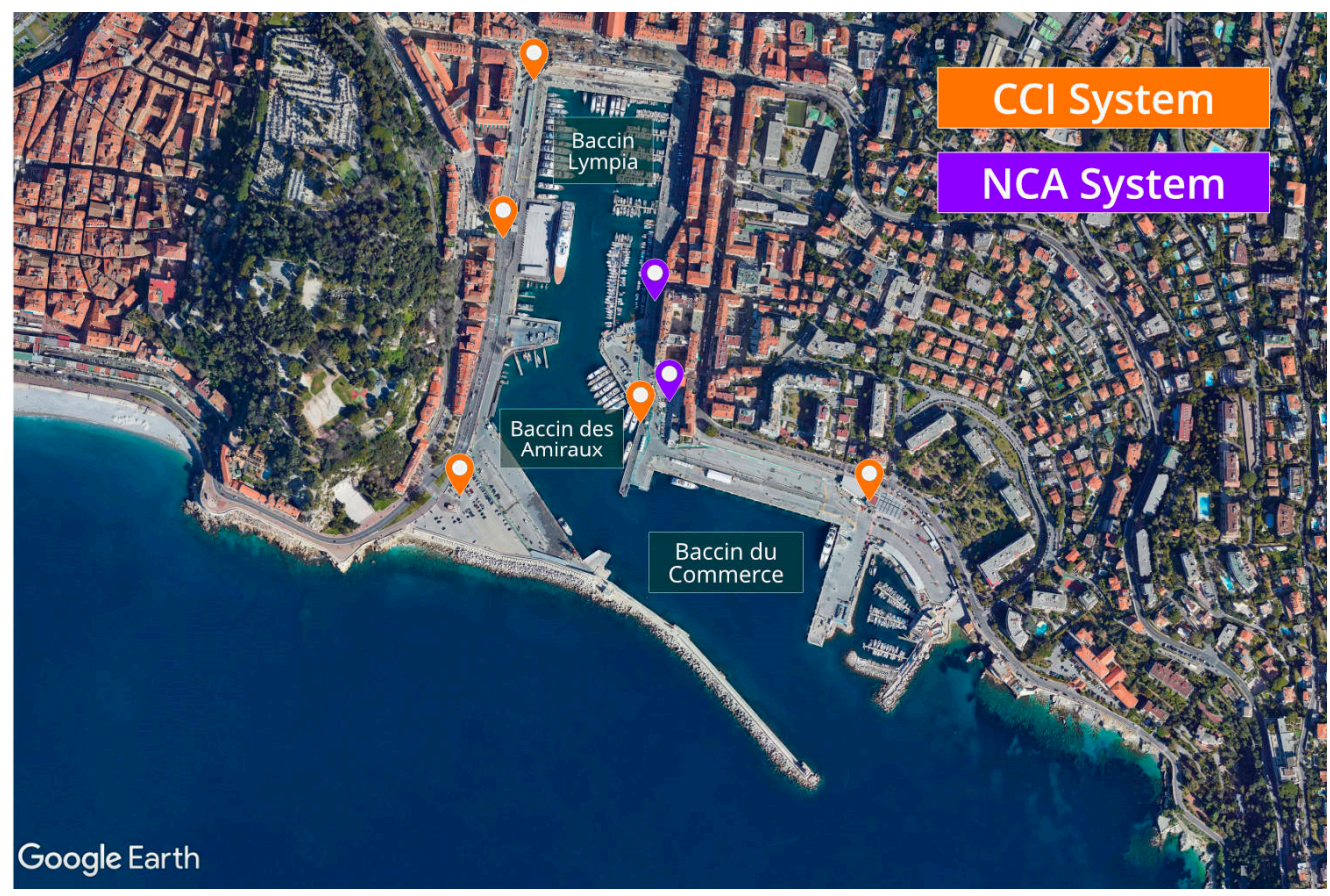

Figure 4. Positioning of the Nice monitoring systems sound level meters.

Table 3. The monitoring systems in the North Tyrrhenian Sea.

\begin{tabular}{cccc}
\hline Port & Monitoring System & Monitoring Plans $^{\mathbf{1}}$ & Dedicated Staff $^{\text {Do }}$ \\
\hline Bastia & No & No & No \\
Cagliari & No & Yes & Yes \\
Genoa & Yes ${ }^{2}$ & No $^{3}$ & Yes \\
La Spezia & No & Yes & No \\
Livorno & No & No & No \\
Nice & Yes & Yes & Yes \\
Portoferraio & No & No & No \\
\hline
\end{tabular}

${ }^{1}$ Monitoring plans are multi-annual environmental monitoring programs that include, together with noise climate monitoring, water surveys, pollution monitoring and so on. ${ }^{2}$ Property of a concession holder. ${ }^{3}$ Spot measurement only. ${ }^{4}$ Two different monitoring systems are present. 
Monitoring data are collected by the two different bodies, which manage them independently. The data is also distributed in two different formats: the NCA provides raw data in a proprietary data format of the respective two sound level meters in usage; the CCI provides the data in CVS format.

\subsection{Measurement Campaigns}

In Table 4, the purposes of measurement campaigns are shown. Except for the case of Bastia, at the time of the study, noise measurements were done in all the ports investigated.

A report on the previous monitoring campaigns executed in the last 20 years around the port of Genoa states that a common difficulty was to isolate a single predominant noise source from the residual noise. The noise produced by the port is distinguishable at a distance of $500 \mathrm{~m}$ from the port, but the subjective disturbance caused by the noise was difficult to quantify because at those distances, the noise level produced by the port is only 1 or $2 \mathrm{~dB}$ more than the residual noise. The problem is that some of the residual noise could be produced by various sources at the port. Due to the high number of sources and the high distance from them, it is impossible to ascertain their cause using just a sound level meter.

The same problem was found in La Spezia. Thanks to a monitoring campaign undertaken over four weeks by ARPAL in 2015, tonal components in the low-frequency region were measured, but no information on the up-times of the port activities was acquired. So due to the lack of information, it was impossible to determine the source of the tonal component. According to Italian regulations, in the case where the source could be correctly identified, a penalty of $+6 \mathrm{~dB}$ would be applied to the noise level and the noise limit could probably be exceeded. Table 3 shows that only three ports have developed an environmental noise monitoring plan. If provided, the information regarding the previous noise measurements is often incomplete and further investigations in the field are required. Thus, port authorities struggle in quantifying and geolocating the impact of port noise and carrying out effective planning and organization of the port activities.

Table 4. The measurement campaign carried out in the North Tyrrhenian's ports.

\begin{tabular}{|c|c|c|c|c|c|}
\hline Port & $\begin{array}{l}\text { Measurement } \\
\text { Campaigns }\end{array}$ & For PCCA $^{1}$ & For PCRA ${ }^{2}$ & $\begin{array}{c}\text { According to } \\
\text { D.Leg. } 81 / 2008^{3}\end{array}$ & $\begin{array}{c}\text { Corporate Rehabilitation } \\
\text { Plans }\end{array}$ \\
\hline Bastia & No & No & No & No & No \\
\hline Cagliari & Yes & Yes & No & No & No \\
\hline Genoa & Yes & Yes & Yes & Yes & Yes \\
\hline La Spezia & Yes & No & No & No & Yes \\
\hline Livorno & Yes & Yes & No & No & No \\
\hline Nice & Yes & No & Yes & - & Yes \\
\hline Portoferraio & Yes & No & No & No & No \\
\hline
\end{tabular}

A description of the more relevant monitoring campaign reported will be presented in the following subsections.

6.2.1. Monitoring Campaign on the Correlation between Port Activity and Terrestrial Traffic on Livorno

The monitoring campaign, conducted in Livorno between the end of 2017 and the beginning of 2018 by the Environmental Protection Regional Agency of Tuscany (ARPAT), resulted in the correlation of road traffic and noise levels in specific points of the road network with the number of passengers and freight vessels docked and sailed on the port.

The result of the survey described the acoustic environment of the area and highlighted that the influence of the port induced traffic is relevant in some specific hours only, i.e., at berths and departures of ships. The study was accomplished through the execution of spot and continuous environmental noise measurements (Figure 5) coupled with traffic flow measurement at the port's gates. 


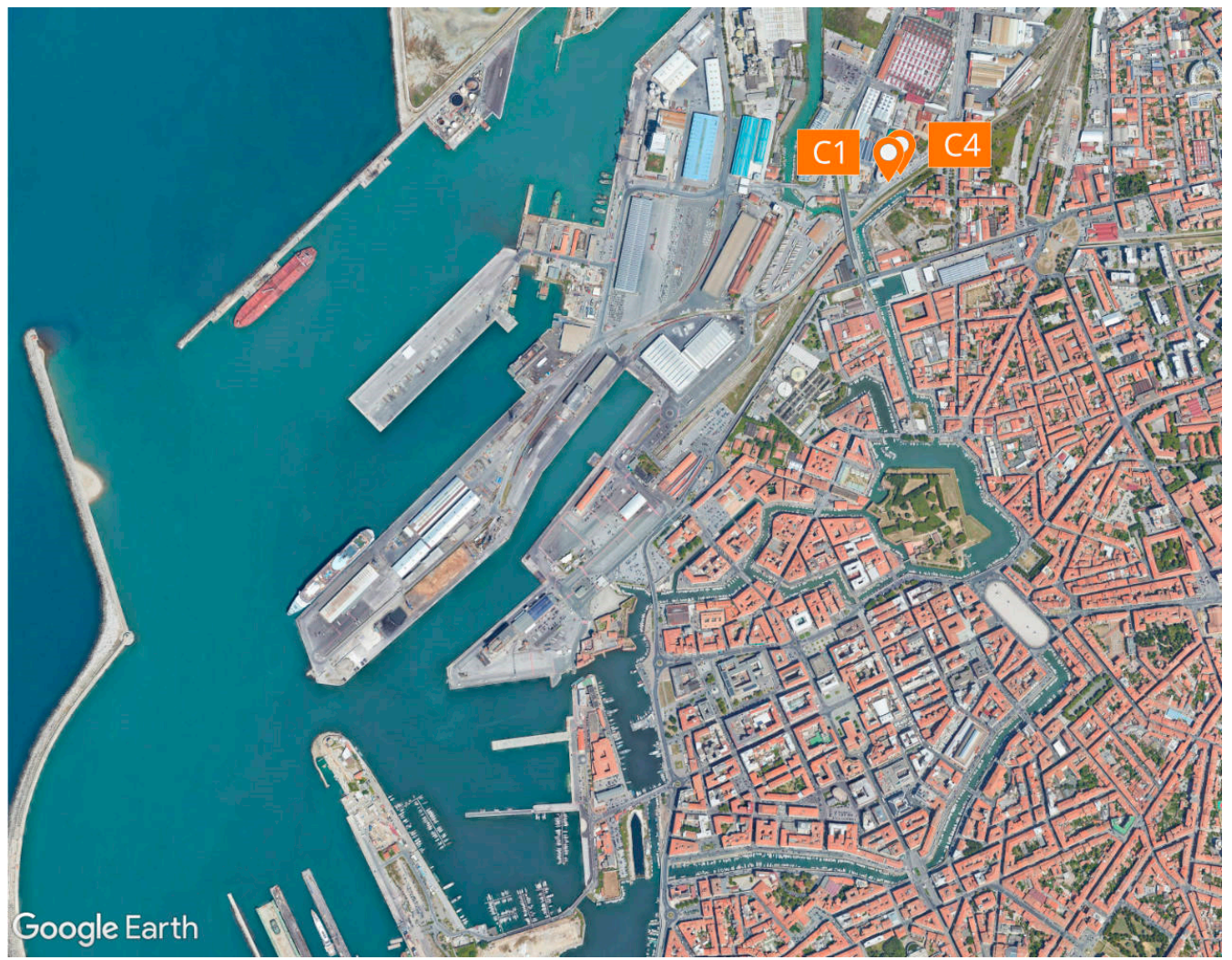

Figure 5. Positioning of the measurement point in Livorno.

The measurement results reported in Table 5 highlight that the relevance of the port induced traffic noise is evident during night time in the summer, due to the more intensive port activity. The measurements $\mathrm{C} 1$ and C4 were performed on the same road stretch but in a different season. In Table 6, the data on terrestrial traffic and the number of moorings of sailing ships during July and October are reported. Despite port activities being more intense in July than in October, noise levels during the day are the same. The period of noise monitoring is not totally covered for traffic monitoring, however, in Figures 6 and 7, a more intense flux is noticeable from 22:00 to 08:00 in the October period. It can be inferred that during the daytime, the noise generated from the traffic that is not related to the port is far higher than the port-related noise. On the contrary, at nighttime, human activities in the city are fewer, and the port-induced traffic noise becomes relevant, and in the summer night period, noise levels were more than $3 \mathrm{~dB}(\mathrm{~A})$ higher compared to the ones measured during the autumn.

Table 5. The noise levels in different seasons on the same road-arch in Livorno.

\begin{tabular}{cccc}
\hline Location & Measurement Period & Day Period LAeq, RT dB(A) & Night Period LAeq, RTdB(A) \\
\hline C1 & 4-11 October 2017 & 67.1 & $56.4^{1}$ \\
\hline C4 & 7-13 July 2018 & 67.0 & $60.3^{1}$ \\
\hline
\end{tabular}

${ }^{1}$ A more than $3 \mathrm{~dB}$ higher level was found in summer nights when the number of sailing boats and departures is higher. The day period goes from 06:00 to 22:00. 
Table 6. The number of ships and vehicle flux in October and in July.

\begin{tabular}{|c|c|c|c|}
\hline & & $5-7 / 10 / 2017$ & $5-8 / 7 / 2018$ \\
\hline \multicolumn{2}{|c|}{ Light vehicle flux [vehicle/h] } & 147.7 & 164.3 \\
\hline \multicolumn{2}{|c|}{$\begin{array}{l}\text { Heavy vehicle flux } \\
\text { [vehicle/h] }\end{array}$} & 49.9 & 87.0 \\
\hline \multirow{3}{*}{ Ships } & Friday & $\begin{array}{l}\text { 6/10 h } 6.30 \text { from Olbia } \\
\text { 6/10 h } 6.30 \text { from Golfo Aranci } \\
\text { 6/10 h } 17.35 \text { from Bastia }\end{array}$ & $\begin{array}{l}\text { 6/7 h } 6.30 \text { from Olbia } \\
\text { 6/7 h } 6.30 \text { from Golfo Aranci } \\
\text { 6/7 h } 11.30 \text { from Bastia } \\
\text { 6/7 h } 20.15 \text { from Bastia } \\
\text { 6/7 h } 21.55 \text { from Golfo Aranci } \\
\text { 6/7 h } 21.55 \text { from Golfo Aranci } \\
\text { 6/7 h } 22.30 \text { from Bastia }\end{array}$ \\
\hline & Saturday & $\begin{array}{c}\text { 7/10 h 6,30 from Olbia } \\
7 / 10 \text { h } 6,30 \text { from Golfo Aranci } \\
7 / 10 \text { h } 12.35 \text { to Bastia } \\
7 / 10 \text { h } 12.35 \text { to Bastia } \\
7 / 10 \text { h } 17.55 \text { from Golfo Aranci }\end{array}$ & $\begin{array}{c}7 / 6 \text { h } 6.30 \text { from Olbia } \\
7 / 6 \text { h } 6.30 \text { from Olbia } \\
7 / 6 \text { h } 6.30 \text { from Olbia } \\
7 / 6 \text { h } 6.30 \text { from Olbia } \\
7 / 6 \text { h } 6.30 \text { from Golfo aranci } \\
\text { 7/6 h } 12.35 \text { from Bastia } \\
7 / 6 \text { h } 13.15 \text { from Portovecchio } \\
7 / 6 \text { h } 14.30 \text { from Golfo aranci } \\
7 / 6 \text { h } 19.45 \text { to Bastia } \\
7 / 6 \text { h } 19.45 \text { from Bastia } \\
7 / 6 \text { h } 22.00 \text { from Bastia } \\
7 / 6 \text { h } 22.30 \text { from Olbia }\end{array}$ \\
\hline & Sunday & & $\begin{array}{c}\text { 8/6 h } 6.30 \text { from Olbia } \\
\text { 8/6 h } 6.30 \text { from Golfo Aranci } \\
\text { 8/6 h } 14.30 \text { from Golfo Aranci } \\
\text { 8/6 h } 17.30 \text { to Bastia } \\
\text { 8/6 h } 20.15 \text { to Bastia }\end{array}$ \\
\hline \multicolumn{2}{|c|}{ Total number of ships } & 8 & 20 \\
\hline
\end{tabular}

C1 point $-5-7 / 10 / 2017$

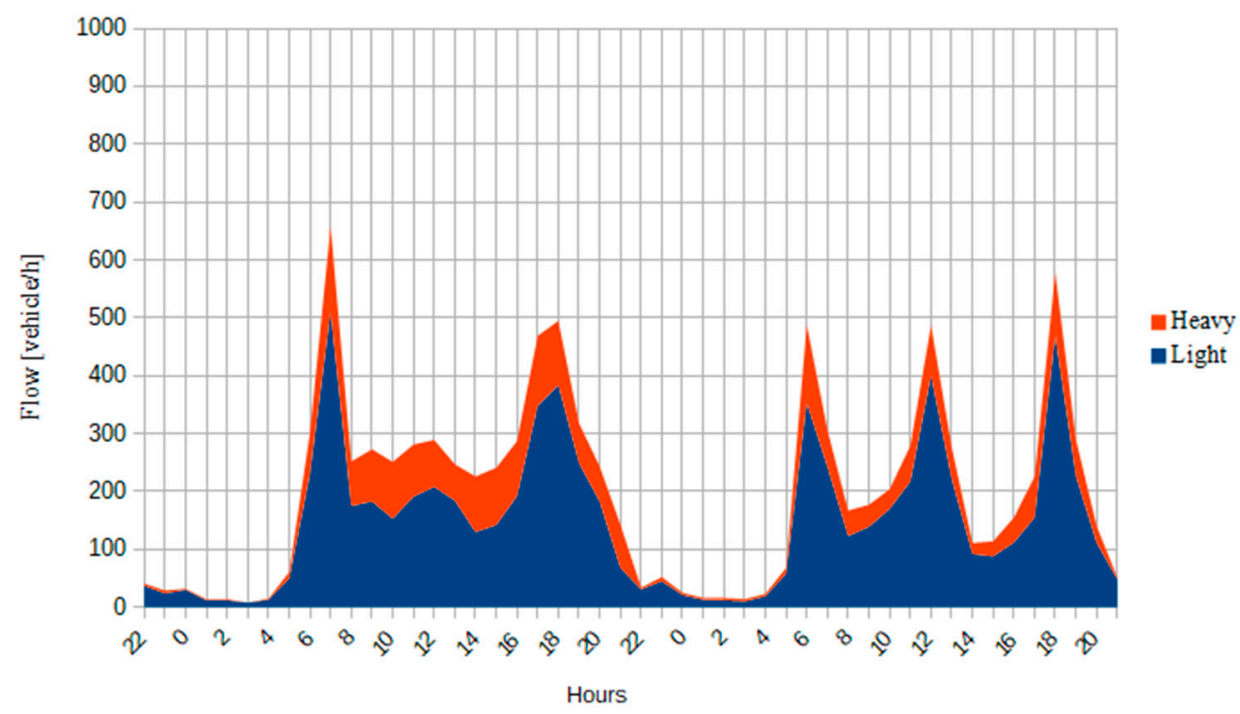

Figure 6. Vehicle flux measured in the proximity of Point $\mathrm{C} 1$ in October. In orange is the heavy vehicle flux, in blue is the light vehicle flux. 


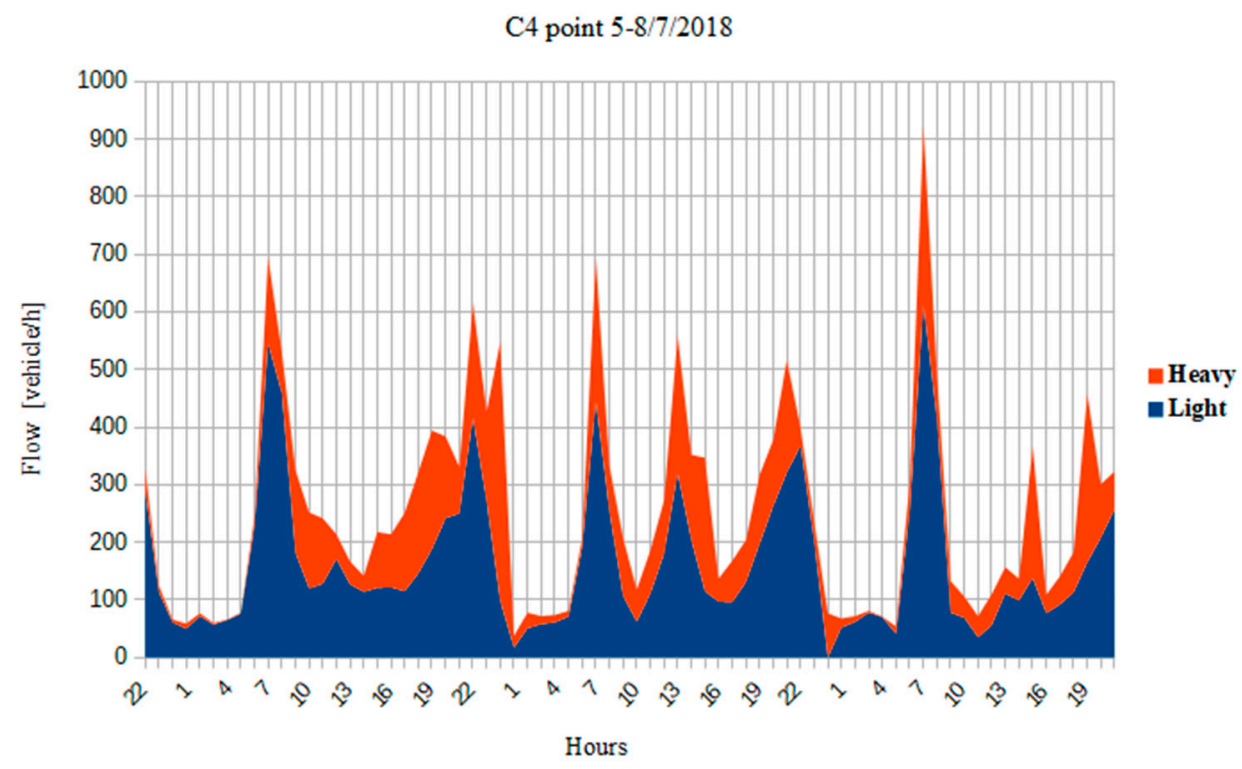

Figure 7. Vehicle flux measured in the proximity of Point C1 in July. In orange is the heavy vehicle flux, in blue is the light vehicle flux.

\subsubsection{Noise Assessment of Small Vessels for Action Planning in Canal Cities}

Inside the port of Livorno, ARPAT and the Department of Physics of the University of Pisa performed a preliminary study on noise impact generated by recreational craft in the city's internal canals [36]. Through long and short duration pass-by measures, the emissions of two distinct categories of small craft were characterized: recreational craft and small and medium-sized fishing vessels and boats of the police force.

Noise emission was characterized at different transit speeds and taking into account different scenarios, noise maps have been produced (Figure 8). The data was presented in terms of $L_{\text {den }}$ (day-evening-night noise level or day evening night noise indicator), which is the A-weighted $\mathrm{L}_{\mathrm{eq}}$ over a whole day with a penalty of $10 \mathrm{~dB}(\mathrm{~A})$ for night-time noise (22:00-06:00) and $5 \mathrm{~dB}(\mathrm{~A})$ for evening noise (20:00-22:00). At current flow and speed conditions, current noise does not exceed the limits. However, if an increase in traffic should take place, a consequent rise in complaints about noise disturbances is expected.

\subsection{Noise Impact}

Since no detailed classification of complaints was reported in the answers, the analysis was based only on the synthesis provided by the public bodies reported in the questionnaires' answers. From the analysis, the seasonal features of the disturbance arose clearly.

In the absence of actions aimed at minimizing the acoustic impact, because of the huge national and international investments that have increased the interchanges by sea and, therefore, the ship traffic generated, the current picture (already characterized by some criticalities) could certainly worsen. In the following subsections, the data will be described more precisely.

\subsubsection{Complaints}

The questionnaire asked not only for history and classification of the complaints but also for a geo-referenced map; however, this last request was not fulfilled. Question 3.a in the section "Complaints and committees" asks "What sources do citizens who make complaints perceive as most disturbing?" and questions 3.b and 3.c ask for a geo-referenced map with complainants, sources, and times of disturbance, and a map of receivers and sources and times of disturbance. Question 3.d asked about the most significant noise sources and to track them on a map. 


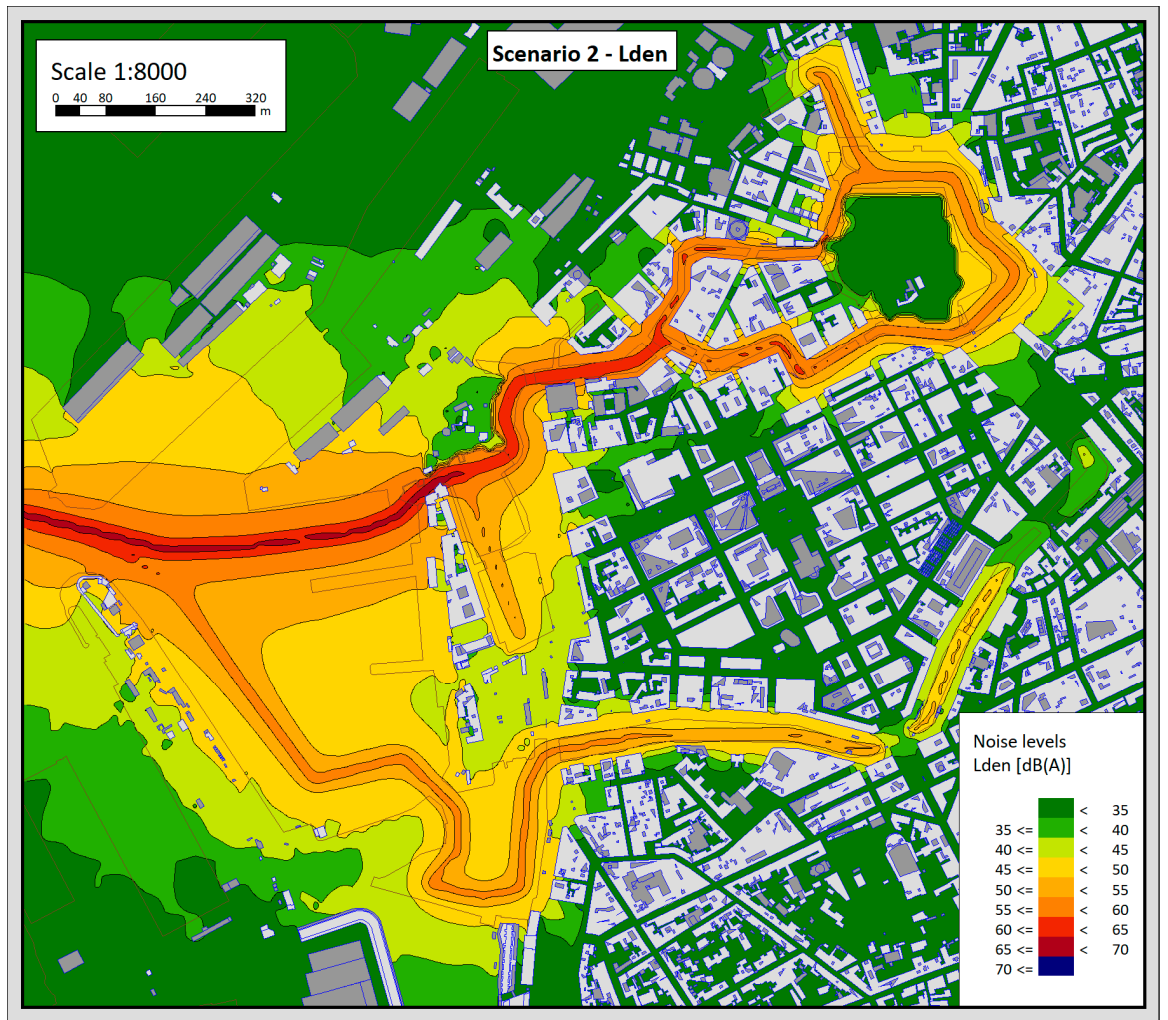

Figure 8. Map of the noise produced by small vessels in the port and internal canals of Livorno.

To date, La Spezia and Nice are the only two ports that have precise data on the number of complaints and their type (Table 7). However, even in those cases, there has been no effort to geolocalize complaints and the disturbing sources and no catalog or acoustical characterization is available.

Table 7. Complaints and committees in the investigated ports.

\begin{tabular}{ccccc}
\hline Port & History of Complaints & Noise Prevention Committees & Seasonality & Day Period \\
\hline Bastia & No & No & Summer & Day \\
Cagliari & No & Yes & - & - \\
Genoa & No & Yes & Summer & Night \\
La Spezia & Yes ${ }^{1}$ & Yes & - & Night \\
Livorno & No & Unknow & Summer & Night \\
Nice & Yes ${ }^{2}$ & Yes & Summer & Both \\
Portoferraio & No & Unknow & Summer & Night \\
\hline
\end{tabular}

${ }^{1}$ Six per year. ${ }^{2}$ In a number of 46 between 2017 and 2018.

\subsubsection{Seasonality}

The two rightmost columns of Table 7 show for each port, the season and the period of the day in which the complaints are more frequent. Excluding the port of Bastia and the port of Nice, the nighttime period results are the most critical; while, excluding Cagliari and La Spezia, the most critical season is Summer.

\section{Discussion}

Compared to other major noise sources, port noise is the least investigated in the past and there is a deep gap in regulations at both the European level and the national level for Italy and France. The RUMBLE, MON ACUMEN, and REPORT projects have undertaken a survey on port noise in the area of the North Tyrrhenian Sea. All the historical data on previous noise monitoring campaigns, the 
data on currently active continuous noise monitoring systems, the information on noise prevention committees, and citizens' complaints related to port noise were collected, a classification of the ports and the main noise sources were presented, noise maps were requested in order to define the actual state-of-the-art of port noise in the area of interest in terms of expositions of citizens and the awareness of port authorities.

A big effort was taken in order to collect all the information from all the various project partners but some of them did not collaborate enough in that process even after multiple e-mail requests and a reiteration of the request during project meetings and the development of a dedicated web-based application. Moreover, none of the subjects were able to answer all the questions and to provide all the required information.

Because the goal was not a statistical analysis of answers, but informative description of the harbor noise management, the collected information has been considered sufficient for the purposes of the project task. The few data collected shows the low level of awareness concerning port noise issues: this is a result that future studies must take into account.

In terms of previous measurement campaigns, a direct comparison between the different ports is not possible because the type of measurements differs from port to port in the aims and targets. In two cases (Cagliari and Genoa), measurements were performed during the realization of the PCCA (Piano Comunale di Classificazione Acustica, Italian for municipal acoustical classification plan, also known as acoustic zoning) and in the other cases, the noise produced by the port was not taken into account during the process or it was considered not relevant. Additionally, for the PCRA (Piano Comunale di Risanamento Acustico, Italian acronym for the municipal acoustic rehabilitation plan), port noise measurements were carried out in only two cases (Genoa and Nice). The column named "According to D.Leg. $81 / 2008$ " indicates if the measure was performed according to the Italian law concerning the protection of health and safety at work. Even if the target of the paper is not the evaluation of the workers' exposure to noise, the information confirms that the number of noise measurement in the ports of interest is very low, probably due to the high level of complexity of the port or to the low level of attention given to noise problems. Only within the ports of Genoa, La Spezia and Nice noise measurements were performed for a Corporate Rehabilitation Plan for some of the industries operating inside the port boundaries.

Furthermore, considering the report on the previous noise monitoring campaigns in Genova, it emerges that there is a real difference between the modalities followed by the various port authorities in facing the difficult task of describing the acoustic environment and the complex activities that act as a source. Indeed, to date, neither a methodology for monitoring nor a common strategy that can increase the information acquired by the various bodies exists. In a bustling environment, like a port, isolating a specific source and determining its relevance is a toilsome task. For this reason, a complex instrument known as the Acoustic Camera will be useful. An Acoustic Camera is a device capable of creating a graphical representation of the noise environment. Such a device uses an array of microphones in conjunction with an optical camera to create images like the one shown in Figure 2. Thanks to the beam-forming technique, the sound power of the sources are represented by a color figure superposed on the images captured from the optical camera. An acoustic camera was already used in the port of Livorno and is intended to be used more intensively in the near future. The port induced terrestrial traffic monitoring campaigns in Livorno, shows that the terrestrial traffic flow can be influenced by the port activities. Unfortunately, for a citizen disturbed by terrestrial traffic noise, it is almost impossible to understand the amount of traffic that is related to the port so, in the case of a complaint being made, there is the possibility that the port could not be reported as the disturbing noise source. This consideration could explain the low number of complaints collected by the port authorities. The fact that only Nice and La Spezia ware capable of providing the exact number of complaints highlights the low level of awareness that the port authorities have regarding this issue. This conclusion is also supported by the absence of staff devoted to noise control in the majority of the ports studied. 


\section{Conclusions}

Within the INTERREG Marittimo-Maritime projects, the problem of port noise in the area of the upper Tyrrhenian Sea was addressed involving both the port authorities and the other local realities affected by the problem by submitting a survey. Thanks to this survey, objective and subjective data were collected. This data was useful to understand how port-noise is currently perceived.

The study has highlighted the difficulties encountered by the port authorities in noise monitoring activities, the lack of a shared approach between them, and the lack of data on noise impact and complaints. On the other hand, some examples of good practices were also found. The advanced noise monitoring system based at the port of Nice can be extended to other ports and information to the citizens about noise pollution can be spread. Related studies demonstrate a direct correlation between passenger and freight traffic and induced terrestrial traffic, and between boating activities and the noise exposition of citizens in the internal canals. Those works focus the attention on future developments in terms of traffic growth due to the recent investments in maritime traffic. The analysis of the state-of-the-art of port noise shows a strong need to develop innovative, sustainable, and efficient noise pollution management technologies in order to not compromise the growth of the maritime trade. The use of instruments like the acoustic camera will be helpful in improving the knowledge of the port environment and for easier and faster real-time identification of dominant noise sources.

Innovative instruments in terms of noise mitigation, noise monitoring, and noise modeling will be developed during the proceedings of the Interreg program and, in particular, during the REPORT, MON ACUMEN, and RUMBLE projects. The collected data represents the beginning of the construction of an integrated database on port noise, which could become a tool for planning and control not only for the cross-border area activities but also as a model for other areas in the European Union. An effective noise emission control and complaint reduction are crucial to avoid hindering the development of the maritime traffic which, compared to the other transportation technologies like railways and roads, provides evident benefits in terms of environmental sustainability.

Author Contributions: Conceptualization, G.L.; Data curation, M.B.; Formal analysis, M.B.; Funding acquisition, F.F. and G.L.; Investigation, M.B., D.P., F.F. and G.L.; Methodology, G.L; Project administration, F.F. and G.L.; Supervision, F.F. and G.L.; Writing-original draft, M.B.; Writing-review and editing, M.B., D.P., F.F. and G.L. All authors have read and agreed to the published version of the manuscript.

Funding: This work was supported by the funding from the European Union's INTERREG IT-FR "Maritime" Programme (RUMBLE: G36H17000000007, MON ACUMEN: B52H17000770003, REPORT: D36C18000220006).

Acknowledgments: This work has been developed in the framework of the EU cooperation projects RUMBLE, MON ACUMEN, and REPORT (Rumore e Porti). The authors wish to thank Alessandro Del Pizzo and Sandra Hill for linguistic support and proof reading of the article.

Conflicts of Interest: The authors declare no conflict of interest.

\section{References}

1. Recio, A.; Linares, C.; Banegas, J.R.; Díaz, J. Road traffic noise effects on cardiovascular, respiratory, and metabolic health: An integrative model of biological mechanisms. Environ. Res. 2016, 146, 359-370. [CrossRef] [PubMed]

2. Dratva, J.; Phuleria, H.C.; Foraster, M.; Gaspoz, J.M.; Keidel, D.; Künzli, N.; Liu, L.J.; Pons, M.; Zemp, E.; Gerbase, M.W.; et al. Transportation noise and blood pressure in a population-based sample of adults. Environ. Health Perspect. 2011, 120, 50-55. [CrossRef] [PubMed]

3. Babisch, W.; Beule, B.; Schust, M.; Kersten, N.; Ising, H. Traffic noise and risk of myocardial infarction. Epidemiology 2005, 16, 33-40. [CrossRef] [PubMed]

4. Babisch, W.; Swart, W.; Houthuijs, D.; Selander, J.; Bluhm, G.; Pershagen, G.; Dimakopoulou, K.; Haralabidis, A.S.; Katsouyanni, K.; Davou, E.; et al. Exposure modifiers of the relationships of transportation noise with high blood pressure and noise annoyance. J. Acoust. Soc. Am. 2012, 132, 3788-3808. [CrossRef] [PubMed] 
5. Vienneau, D.; Schindler, C.; Perez, L.; Probst-Hensch, N.; Röösli, M. The relationship between transportation noise exposure and ischemic heart disease: A meta-analysis. Environ. Res. 2015, 138, 372-380. [CrossRef] [PubMed]

6. Van Kempen, E.; Babisch, W. The quantitative relationship between road traffic noise and hypertension: A meta-analysis. J. Hypertens. 2012, 30, 1075-1086. [CrossRef] [PubMed]

7. Jarup, L.; Babisch, W.; Houthuijs, D.; Pershagen, G.; Katsouyanni, K.; Cadum, E.; Dudley, M.L.; Savigny, P.; Seiffert, I.; Swart, W.; et al. Hypertension and exposure to noise near airports: The HYENA study. Environ. Health Perspect. 2007, 116, 329-333. [CrossRef] [PubMed]

8. Basner, M.; Babisch, W.; Davis, A.; Brink, M.; Clark, C.; Janssen, S.; Stansfeld, S. Auditory and non-auditory effects of noise on health. Lancet 2014, 383, 1325-1332. [CrossRef]

9. Guski, R.; Schreckenberg, D.; Schuemer, R. WHO environmental noise guidelines for the European region: A systematic review on environmental noise and annoyance. Int. J. Environ. Res. Public Health 2017, 14, 1539. [CrossRef] [PubMed]

10. Minichilli, F.; Gorini, F.; Ascari, E.; Bianchi, F.; Coi, A.; Fredianelli, L.; Licitra, G.; Manzoli, F.; Mezzasalma, L.; Cori, L. Annoyance judgment and measurements of environmental noise: A focus on Italian secondary schools. Int. J. Environ. Res. Public Health 2018, 15, 208. [CrossRef] [PubMed]

11. Hygge, S.; Evans, G.W.; Bullinger, M. A prospective study of some effects of aircraft noise on cognitive performance in schoolchildren. Psychol. Sci. 2002, 13, 469-474. [CrossRef] [PubMed]

12. Lercher, P.; Evans, G.W.; Meis, M. Ambient noise and cognitive processes among primary schoolchildren. Environ. Behav. 2003, 35, 725-735. [CrossRef]

13. Klatte, M.; Bergström, K.; Lachmann, T. Does noise affect learning? A short review on noise effects on cognitive performance in children. Front. Psychol. 2013, 4, 578. [CrossRef] [PubMed]

14. Muzet, A. Environmental noise, sleep and health. Sleep Med. Rev. 2007, 11, 135-142. [CrossRef] [PubMed]

15. HADA. Available online: http://ec.europa.eu/environment/life/project/Projects/index.cfm?fuseaction=search. dspPage\&n_proj_id=2105 (accessed on 13 January 2020).

16. ECO.PORT. Available online: https://www.ecoports.com/ (accessed on 13 January 2020).

17. Van Breemen, T. Good Practice Guide on Port Area Noise Mapping and Management, Noise Management in European Ports (NoMEPorts) Project. LIFE05 ENV/NL/000018. 2008. Available online: https://www.ecoslc. eu/laravel-filemanager/files/common/publications/good_practice_guide.pdf (accessed on 23 February 2020).

18. SIMPLYC. Available online: http://ec.europa.eu/environment/life/project/Projects/index.cfm?fuseaction= search.dspPage\&n_proj_id=2714 (accessed on 13 January 2020).

19. Schenone, C.; Pittaluga, I.; Borelli, D.; Kamali, W.; El Moghrabi, Y. The impact of environmental noise generated from ports: Outcome of MESP project. Noise Mapp. 2016, 3, 26-36. [CrossRef]

20. Anchor. Available online: http://anchorlife.eu/ (accessed on 23 February 2020).

21. Fardella, E.; Prodi, G. The belt and road initiative impact on Europe: An Italian perspective. China World Econ. 2017, 25, 125-138. [CrossRef]

22. RUMBLE. Available online: http://interreg-maritime.eu/it/web/rumble/ (accessed on 28 October 2019).

23. MON ACUMEN. Available online: http://interreg-maritime.eu/it/web/monacumen/ (accessed on 28 October 2019).

24. REPORT. Available online: http://interreg-maritime.eu/it/web/report/ (accessed on 28 October 2019).

25. Eurostat-Gross Weight of Goods Transported to/from Main Ports-Italy. Available online: https://appsso. eurostat.ec.europa.eu/nui/show.do?dataset=mar_go_am_it\&lang=en (accessed on 28 October 2019).

26. Eurostat-Gross Weight of Goods Transported to/from Main Ports-France. Available online: https: //appsso.eurostat.ec.europa.eu/nui/show.do?dataset=mar_go_Am_fr\&lang=en (accessed on 28 October 2019).

27. Eurostat-Volume of Containers Transported to/from Main Ports-Quarterly Data (2017-2018). Available online: https://appsso.eurostat.ec.europa.eu/nui/submitViewTableAction.do (accessed on 28 October 2019).

28. Eurostat-Passengers Transported to/from Main Ports-Italy-Quarterly Data. Available online: https: //appsso.eurostat.ec.europa.eu/nui/show.do?dataset=mar_go_am_it\&lang=en (accessed on 28 October 2019).

29. Eurostat-Passengers Transported to/from Main Ports-France-Quarterly Data. Available online: https: //appsso.eurostat.ec.europa.eu/nui/show.do?dataset=mar_go_am_fr\&lang=en (accessed on 28 October 2019).

30. Interreg Matittimo-IT FR-Maritime. Available online: http://interreg-maritime.eu/ (accessed on 28 October 2019).

31. DECIBEL. Available online: http://interreg-maritime.eu/it/web/decibel/ (accessed on 28 October 2019). 
32. L.I.S.T. PORT. Available online: http://interreg-maritime.eu/it/web/listport/ (accessed on 28 October 2019).

33. Osorio-Tejada, J.L.; Llera-Sastresa, E.; Scarpellini, S. Liquefied natural gas: Could it be a reliable option for road freight transport in the EU? Renew. Sustain. Energy Rev. 2017, 71, 785-795. [CrossRef]

34. Kephalopoulos, S.; Paviotti, M.; Anfosso-Lédée, F. Common Noise Assessment Methods in Europe (CNOSSOS-EU); Publications Office of the European Union: Luxembourg, 2012; Volume 180. [CrossRef]

35. INSPIRE Directive. Available online: https://inspire.ec.europa.eu/ (accessed on 10 January 2020).

36. Bernardini, M.; Fredianelli, L.; Fidecaro, F.; Gagliardi, P.; Nastasi, M.; Licitra, G. Noise Assessment of Small Vessels for Action Planning in Canal Cities. Environments 2019, 6, 31. [CrossRef]

(C) 2020 by the authors. Licensee MDPI, Basel, Switzerland. This article is an open access article distributed under the terms and conditions of the Creative Commons Attribution (CC BY) license (http://creativecommons.org/licenses/by/4.0/). 